\title{
Upaya Humas Direktorat Jenderal Kekayaan Intelektual dalam Membangun Kesadaran Hak Cipta
}

\author{
Avissa Yufen Fabrianne, Yugih Setyanto \\ avissayff@gmail.com,yugihs@fikom.untar.ac.id
}

Fakultas Ilmu Komunikasi Universitas Tarumanagara

\begin{abstract}
Cases of Infringement Copyright which is very common in Indonesia, one of which is piracy. Cite the work of part or all of the creation of another person without including sources that are intentionally included in his own creation so as to make the impression of his work as if his property is called plagiarism. Plagiarism can also be said if other people's creations are reproduced without changing the form or content to be announced, and reproducing other people's creations intentionally and containing commercially. Copyright infringement in Indonesia can cause a bad image for law enforcement in Indonesia. Indonesia gets negative attention from other countries due to severe copyright violations. The Directorate General of Intellectual Property (DJKI) is an Echelon I organizational unit within the Ministry of Law and Human Rights of the Republic of Indonesia, which is tasked with managing and serving the protection of Intellectual Property Rights in Indonesia, one of which is Copyright. The author is interested in knowing the public relations strategy of the Directorate General of Intellectual Property in building awareness of copyright, especially for the people of Indonesia. The purpose of this study is to find out the public relations efforts of the Directorate General of Intellectual Property in building awareness of copyright. The theoretical basis used in this study covers the theory of mass communication, public relations, government public relations, public relations strategies, intellectual property rights and copyright. The research method used in this study was qualitative with a descriptive case study approach. In this study the authors want to know the public relations strategy of the Directorate General of Intellectual Property in building copyright awareness through interviews, observations and other matters related to this research. It can be concluded, the DJKI public relations strategy is by educating the public about the importance of respecting someone's copyright and the importance of registering a work so that it can be protected by the state legally in the event of a copyright infringement.
\end{abstract}

Keywords: Public Relations, PR Efforts, copyright.

\begin{abstract}
Abstrak
Kasus pelanggaran hak cipta yang sangat sering terjadi di Indonesia salah satunya adalah pembajakan. Mengutip karya sebagian atau seluruh ciptaan orang lain tanpa mencantumkan sumber yang sengaja dimasukkan kedalam ciptaannya sendiri agar membuat kesan karya miliknya seolah-olah miliknya disebut plagiarisme. Plagiarisme juga bisa dikatakan apabila ciptaan milik orang lain diperbanyak tanpa mengubah bentuk ataupun isi untuk diumumkan, dan memperbanyak ciptaan orang lain tanpa izin dengan sengaja dan mengandung komersial. Pelanggaran hak cipta di Indonesia dapat menyebabkan citra buruk bagi penegakan hukum di Indonesia. Indonesia mendapat sorotan negatif dari negara lain diakibatkan oleh pelanggaran hak cipta yang parah. Direktorat Jenderal Kekayaan Intelektual (DJKI) adalah sebuah unit organisasi Eselon I di lingkungan Kementerian Hukum dan Hak Asasi Manusia Republik Indonesia, yang bertugas melaksanakan pengelolaan dan pelayan perlindungan Hak Kekayaan Intelektual di Indonesia, salah satunya adalah Hak Cipta.
\end{abstract}


Penulis tertarik untuk mengetahui strategi humas Direktorat Jenderal Kekayaan Intelektual dalam membangun kesadaran terhadap hak cipta terutama untuk masyarakat Indonesia. Tujuan dari penelitian ini adalah untuk mengetahui Upaya humas Direktorat Jenderal Kekayaan Intelektual dalam membangun kesadaran terhadap hak cipta. Dasar teoritik yang digunakan dalam penelitian ini mencangkup teori komunikasi massa, hubungan masyarakat, humas pemerintah, strategi humas, hak kekayaan intelektual dan hak cipta. Metode penelitian yang digunakan dalam penelitian ini adalah kualitatif dengan pendekatan studi kasus deskriptif. Dalam penelitian ini penulis ingin mengetahui strategi humas Direktorat Jenderal Kekayaan Intelektual dalam membangun kesadaran hak cipta melalui wawancara, observasi dan hal-hal lain yang terkait dengan penelitian ini. Dapat disimpulkan, strategi humas DJKI adalah dengan mengedukasi masyarakat tentang pentingnya menghargai hak cipta milik seseorang dan pentingnya mendaftarkan suatu karya agar bisa dilindungi oleh negara secara hukum jika terjadi suatu pelanggaran hak cipta.

Kata Kunci: humas, upaya humas, hak cipta

\section{Pendahuluan}

Kasus pelanggaran hak cipta yang ada merupakan kasus yang sudah sejak lama menjadi masalah rumit baik di Indonesia maupun negara lainnya. Pelanggaran hak cipta memiliki dampak baik dari segi kerugian material bagi pencipta. Hak cipta terbagi menjadi hak ekonomi dan hak moral. Pemilik hak yang merasakan dampak dari pelanggaran hak cipta yaitu menurunnya motivasi untuk berkreasi. Jika kondisi ini terjadi terus menerus, maka besar kesempatan menurunnya potensi kreativitas milik negara yang akan berefek pada ekonomi nasional.

Indonesia sekarang ini tercatat sebagai negara peringkat keempat pelanggar hak cipta di dunia. Kondisi yang memprihatinkan bahkan menjadi sorotan dunia internasional. Menurut data dari US Trade Representative (dikutip dari https://ustr.gov/sites/ diakses pada tanggal 26 Agustus 2018), pelanggaran hak cipta di Indonesia dari tahun ke tahun bukannya menurun, tetapi malah meningkat. Angka pembajakan pada tahun 2018 jumlah pembajakan meningkat hingga mencapai 500 $\%$, membuat Indonesia masuk dalam kategori Priority Watch List.

Kasus pelanggaran hak cipta yang sangat sering terjadi di Indonesia salah satunya adalah pembajakan. Mengutip karya sebagian atau seluruh ciptaan orang lain tanpa mencantumkan sumber yang sengaja dimasukkan kedalam ciptaannya sendiri agar membuat kesan karya miliknya seolah-olah miliknya disebut plagiarism. Plagiarisme juga bisa dikatakan apabila ciptaan milik orang lain diperbanyak tanpa mengubah bentuk ataupun isi untuk diumumkan, dan memperbanyak ciptaan orang lain tanpa izin dengan sengaja dan mengandung komersial.

Peraturan Perundang Undangan yang mengatur permasalahan hak cipta diatur dalam UU Hak Cipta No. 19 tahun 2002 yang mengatur aturan dan sanksi hukum yang akan diberikan untuk para pelanggar hak cipta baik perdata maupun pidana.

Pelanggaran hak cipta di Indonesia dapat menyebabkan citra buruk bagi penegakan hukum di Indonesia. Indonesia mendapat sorotan negatif dari negara lain diakibatkan oleh pelanggaran hak cipta yang parah. Peran dari pemerintah, penegak hukum dan lapisan masyarakat perlu ditingkatkan guna mengikis pelaku pembajakan hak cipta.

Alasan dari pihak yang melanggar hak cipta adalah mencari keuntungan finansial dan faktor ekonomi. Sehingga mengabaikan kepentingan para pencipta dan pemegang izin hak cipta. 
Direktorat Jenderal Kekayaan Intelektual (DJKI) adalah sebuah unit organisasi Eselon I di lingkungan Kementerian Hukum dan Hak Asasi Manusia Republik Indonesia, yang bertugas melaksanakan pengelolaan dan pelayan perlindungan Hak Kekayaan Intelektual di Indonesia, salah satunya adalah Hak Cipta.

Oleh karena itu, penulis tertarik untuk melihat bagaimana Upaya humas Direktorat Jenderal Kekayaan Intelektual Kementerian Hukum dan HAM Membangun Kesadaran Hak Cipta.

Berdasarkan latar belakang tersebut mengarahkan penulis dalam menetapkan judul skripsi ini, yaitu : "Upaya Humas Direktorat Jenderal Kekayaan Intelektual Kementerian Hukum dan HAM dalam Membangun Kesadaran Hak Cipta”.

\section{Metode Penelitian}

Metode penelitian yang digunakan penulis untuk menganalisa upaya Direktorat Jenderal Kekayaan Intelektual adalah berupa metode penelitian kualitatif. Deniz dan Lincoln (dalam Moleong, 2009: 5) menyatakan bahwa penelitian kualitatif adalah penelitian yang menggunakan latar alamiah, dengan maksud menafsirkan fenomena yang terjadi dan dilakukan dengan jalan melibatkan berbagai metode yang ada. Metode yang biasanya dimanfaatkan adalah wawancara, pengamatan, dan pemanfaatan dokumen. Sedangkan menurut Bodgan dan Taylor (1975: 5) mendefinisikan metodologi kualitatif sebagai prosedur penelitian yang menghasilkan data deskriptif berupa kata-kata tertulis atau lisan dari orang-orang dan perilaku yang diamati.

Dalam penelitian ini yang menjadi subjek penelitian adalah Kepala Sub Bag Humas Direktorat Jenderal Kekayaan Intelektual, Irma Mariana dan Meirina Alwie, sebagai narasumber kedua dalam penelitian ini.

Dalam penelitian ini, peneliti menggunakan beberapa metode pengumpulan data untuk dapat mengumpulkan data dan juga informasi yang lebih dalam dengan berbagai cara, yaitu wawancara, observasi, studi kepustakaan, dan penelusuran data online.

Teknik analisa data yang digunakan pada penelitian ini adalah tenik analisis data kualitatif Miler dan Huberman. Menurut Miler dan Huberman (1992) dalam Gunawan (2014: 210) terdapat 3 teknik analisis data yaitu reduksi data, penyajian data, dan kesimpulan atau verifikasi.

\section{Hasil Temuan dan Diskusi}

Upaya Humas Direktorat Jenderal Kekayaan Intelektual: sesuai dengan Peraturan Menteri Negara Pendayagunaan Aparatur Negara dan Reformasi Birokrasi Republik Indonesia Nomor 30 Tahun 2011, menjelaskan bahwa, Humas Pemerintah merupakan lembaga milik pemerintah yang melakukan fungsi di bidang informasi dan komunikasi, agar tercipta hubungan yang baik dengan publik agar menciptakan citra dan reputasi yang baik. Sesuai dengan teori yang dijelaskan diatas bisa dilihat bahwa tugas humas, yaitu:

Publikasi: Praktisi humas harus mendukung program pemerintah untuk "berbicara baik". Praktisi humas harus terlibat dalam mengedukasi masyarakat agar informasi yang layak konsumsi lah yang patut untuk disebarluaskan, bukan berita bohong atau menebar kebencian. Peran humas memberikan informasi kepada publik terkait kinerja pemerintah dan departemennya sendiri. 
Di era banyaknya informasi, humas juga harus bisa selektif dan memahami peta media saat ini. Media massa berkembang pesat di Indonesia, terutama mediamedia massa berbasis digital. Sebagai PR yang merepresentasikan suatu perusahaan, harus bisa memanfaatkan berbagai siaran komunikasi dan informasi secara efektif.

Humas pemerintah diharuskan mengenali tugas humas sebagai penyebar informasi dengan mengembangkan konten informasi terhadap publik, terutama mengenai kinerja lembaganya. Seperti apa yang dikatakan oleh Ibu Irma Mariana selaku Kab Sub Bag Humas DJKI yaitu,

"Kalau secara tugas pokok dan fungsi humas itu adalah suatu sub bagian yang berada dibawah sekertariat yang berada dibawah Jenderal Kekayaan Intelektual sebagai layanan informasi ataupun pemberi informasi ke masyarakat, baik itu informasi berupa kebijakan, produk-produk kekayaan intelektual, sosialiasi, ataupun pengaduan masyarakat dll."

Berdasarkan penjelasan diatas disebutkan bahwa Humas DJKI sebagai layanan informasi dan pemberi informasi yaitu memberikan dengan cara publikasi kepada masyarakat. yaitu memberikan dengan cara publikasi kepada masyarakat.

Inform: Humas pemerintah harus mampu membangun sinergi agar komunikasi yang dilakukan mampu membangun kepercayaan publik yang lebih baik. Komunikasi publik yang efektif menjadi tantangan yang dihadapi humas pemerintah.

Hal ini juga tidak terlepas dari fakta bahwa saat ini berbagai informasi membanjir dari segala arah. Masyarakat tidak lagi dihadapkan pada persoalan mencari informasi, tetapi lebih disibukkan untuk memilih informasi. Humas juga harus mampu memilih informasi yang tepat. Humas harus mendukung program pemerintah untuk "berbicara baik" di publik. Praktisi humas juga harus terlibat dalam mengedukasi masyarakat agar informasi yang layak konsumsi lah yang patut untuk disebarluaskan, bukan berita yang tidak jelas dan tidak dapat dibuktikan.

Publikasi: Publikasi yaitu setiap fungsi dan tugas PR adalah menyelenggarakan publikasi atau menyebarluaskan informasi melalui berbagai media tentang aktivitas atau kegiatan perusahaan atau organisasi yang pantas untuk diketahui oleh publik.

Perkembangan dunia kehumasan bergerak cepat di era reformasi dan teknologi. Peluang besar bahwa PR harus bisa menempatkan PR sebagai peran strategis dalam fungsi manajemen. PR harus bertransformasi dan berevolusi. Humas semakin dituntut tidak hanya sebagai mulut dari sebuah organisasi, tapi juga menjadi mata dan telinga bagi perusahaan.

Media Sosial menjadi salah satu hal yang harus dipahami oleh praktisi PR. Jumlah pengguna media sosial yang begitu banyak dan berkembang, berbagi dan bersosialisasi. Esensinya adalah PR dan media sosial sudah menjadi perangkat yang saling berkaitan dan punya peran yang besar. Praktisi PR terus berkembang karena mau tidak mau praktisi humas harus berkembang di luar bidang Komunikasi dan PR semata. Di era banyaknya informasi, humas juga harus bisa selektif dan memahami media saat ini. Media massa berkembang pesat di Indonesia, terutama media-media massa berbasis digital. Sebagai PR yang merepresentasikan suatu instansi, harus bisa memanfaatkan berbagai siaran komunikasi dan informasi secara efektif.

Kehumasan juga harus mampu memilah dan memilih informasi yang tepat. Praktisi humas harus mendukung program pemerintah untuk "berbicara baik". Praktisi humas harus terlibat dalam mengedukasi masyarakat agar informasi yang layak konsumsi lah yang patut untuk disebarluaskan, bukan berita bohong atau menebar kebencian. Peran humas memberikan informasi kepada publik terkait kinerja pemerintah dan departemennya sendiri. 
Berdasarkan penjelasan di atas disebutkan bahwa Humas DJKI sebagai layanan informasi dan pemberi informasi yaitu memberikan dengan cara publikasi kepada masyarakat.

Image: Seiring berkembangnya tantangan yang dihadapi oleh kehumasan yang semakin kompleks. Oleh karena itu, para praktisi PR harus paham dalam membangun reputasi, mensosialisasikan hal yang positif kepada publik dan stakeholder-nya.

Humas di pemerintahan sama halnya dengan kehumasan di sektor swasta, perannya sangat krusial dan kritikal. Humas harus membangun kepercayaan publik dan reputasi. Salah satunya, peran mereka memberikan informasi kepada publik terkait kinerja pemerintah dan departemennya sendiri. Termasuk juga bagaimana memberikan informasi yang tepat sasaran. Komunikasi yang baik diharapkan mampu membangun ruang publik serta memberikan jalan untuk proses komunikasi dan informasi seimbang antara publik dengan pemerintah dan sebaliknya.

Dari analisa dan pembahasan diatas dapat disimpulkan bahwa Humas DJKI sedang berjuang untuk membangun kesadaran hak cipta bagi masyarakat dengan upaya untuk menginformasikan, mengedukasi, menyebarkan, dan meningkatkan citra yang baik di masyarakat. Walaupun dampaknya mungkin belum dirasakan oleh pihak pemilik hak cipta dan masyarakat umum yang masih belum sadar dan masih melakukan pelanggaran hak cipta. Humas DJKI sebaiknya merealisasikan strategi yang sudah mereka miliki agar dampaknya dapat dirasakan oleh pihak pemilik hak cipta yang merasa dirugikan dan masyarakat umum yang belum tahu pentingnya menghargai hak cipta.

\section{Simpulan}

Berdasarkan hasil analisa upaya humas Direktorat Jenderal Kekayaan Intelektual dalam membangun kesadaran hak cipta, peneliti menyimpulkan beberapa hal, antara lain:

Upaya humas Direktorat Jenderal Kekayaan Intelektual dalam membangun kesadaran hak cipta yang pertama adalah dengan cara menginformasikan segala kebijakan dan informasi yang harus diketahui oleh publik. Terutama informasi mengenai kekayaan intelektual yang didalamnya terdapat hak cipta. Dengan cara mengedukasi publik dengan membangun kesadaran hak cipta. Humas perlu mengembangkan konten-konten untuk masyarakat yang berbasis edukatif, pencerahan, dan pemberdayaan. Komunikasi yang dimanfaatkan menjadi wahana edukasi di ruang publik. Humas berperan sebagai tenaga profesional yang mempersiapkan masyarakat melalui program-program edukasi di ruang publik. Humas DJKI melakukan publikasi atau edukasi ke masyarakat secara masif. Melakukan sosialisasi baik itu secara interface maupun secara online. Interface itu berarti mengedukasi masyarakat melalui sosialisasi-sosialisasi yang dilakukan misalnya ke mahasiswa, perguruan tinggi, dan masyarakat umum. Sedangkan jika melalui online dilakukan melalui media sosial. Menurut ahli, strategi Humas yang digunakan adalah mengedukasi masyarakat melalui sosialisasi secara langsung maupun melalui media sosial.

Kedua, dengan cara menyebarkan informasi tersebut secara benar oleh DJKI. Sebagai humas DJKI yang merepresentasikan lembaga/instansi/perusahaan, harus bisa memanfaatkan berbagai siaran komunikasi dan informasi secara efektif. Humas DJKI juga harus mampu memilah dan memilih informasi yang tepat. Humas DJKI 
sebagai layanan informasi dan pemberi informasi yaitu memberikan dengan cara publikasi dan menyebarkan kepada masyarakat.

Terakhir Humas DJKI memiliki strategi yaitu membangun public trust dan reputasi. Salah satunya, peran mereka memberikan informasi kepada publik terkait kinerja pemerintah dan departemennya sendiri. Termasuk juga bagaimana memberikan informasi yang tepat sasaran. Manajemen komunikasi yang baik diharapkan mampu membangun ruang publik yang memberikan kanal bagi proses komunikasi dan interaksi seimbang antara pemerintah dengan publik dan sebaliknya.

Humas DJKI sedang berjuang untuk membangun kesadaran hak cipta bagi masyarakat dengan strategi untuk menginformasikan, mengedukasi, menyebarkan, dan meningkatkan citra yang baik di masyarakat. Walaupun dampaknya mungkin belum dirasakan oleh pihak pemilik hak cipta dan masyarakat umum yang masih belum sadar dan masih melakukan pelanggaran hak cipta. Humas DJKI sebaiknya merealisasikan strategi yang sudah mereka miliki agar dampaknya dapat dirasakan oleh pihak pemilik hak cipta yang merasa dirugikan dan masyarakat umum yang belum tahu pentingnya menghargai hak cipta.

\section{Ucapan Terima Kasih}

Penelitian ini dapat dibuat oleh saya tidak lain karena berkat rahmat Tuhan Yang Maha Esa, sehingga saya dapat menyelesaikan laporan penelitian dalam mata kuliah skripsi.

Saya menyadari bahwa penyusunan skripsi ini tidak akan terwujud tanpa adanya bantuan dan dorongan dari berbagai pihak. Oleh karena itu pada kesempatan ini saya ingin menyampaikan ucapan terima kasih kepada orang-orang yang telah membatu saya dalam penyusunan penelitian skripsi ini :

1) Bapak Yugih Setyanto S.sos.,M.Si. selaku dosen pembimbing skripsi.

2) Seluruh Dosen Fakultas Ilmu Komunikasi Universitas Tarumanagara.

3) Ibu Irma Marina selaku Kepala Sub Bag Humas Direktorat Jenderal Kekayaan Intelektual dan Saudari Meirina selaku pihak industri film.

4) Kedua orang tua dan keluarga.

5) Kepada sahabat penulis, Shera Aske C, Helen.

6) Serta para narasumber yang telah meluangkan waktunya.

\section{Daftar Pustaka}

Bogdan dan Taylor, 1975 dalam J. Moleong, Lexy. (1989). Metodologi Penelitian Kualitatif. Bandung: Remadja Karya.

Denis McQuail. (1987). Mass Communication Theory (Teori Komunikasi Massa). Jakarta: Erlangga.

Miles, Matthew dan Huberman, A. Michael. (1992). Analisis Data Kualitatif: Buku Sumber Tantang Metode-Metode Baru. Jakarta:UI Press.

Moleong, L.J. (2011). Metodologi Penelitian Kualitatif Edisi Revisi. Bandung: PT Remaja Rosdakarya.

Sunarto. (2003). Humas Pemerintahan dan Komunikasi Persuasif. Wacana.

http://ifpi.org/ 